\title{
THE ROLE OF GUIDES DEVISED BY THE NEW CONSENSUS MOVEMENT PROPONENTS IN POPULARIZING THE IDEALS OF RELIGIOUS FREEDOM IN THE U.S. PRIMARY AND SECONDARY LEVEL EDUCATION
}

\author{
IWONA ZAMKOWSKA \\ Faculty of Philology and Pedagogy, \\ Kazimerz Pulaski University of Technology and Humanities in Radom, \\ Bolesław Chrobry Street, 31, 26-600 Radom, Poland \\ E-mail address: i.zamkowska@uthrad.pl
}

\begin{abstract}
The mid-1980s saw a decisive shift in the approach to religious liberty in American educational system. The shift was the fruit of a concerted effort of numerous influential bodies - both political and religious - which subsequently led to the emergence of the new consensus on teaching about religion and religious liberty in public schools. One of the ways used to facilitate the implementation of the new consensus ideals in public education was the nationwide dissemination of informative materials (guides). Addressed primarily to school officials, teachers and parents, the guides outlined the constitutional and educational role of religion in the public school. The article analyzes a number of selected guides with respect to their religious liberty content. It also discusses the impact they exerted on the U.S. system of education at the primary and secondary school levels.
\end{abstract}

Key words: public education, religious liberty, religious expression.

\section{INTRODUCTION}

In January 2000, at President Clinton's directive to the U.S. Department of Education, the guidelines on the role of religion in public education were mailed to every school principal in the United States. It was the second time in the nation's history that the U.S. president had directed the mailing of the guidelines on religion in public schools. The first instance took place in 1995 and was dispatched to every school superintendent in the nation. This time, however, a packet included a set of educational guides (Carper, \& Hunt, 2009, p. 157). This historic dissemination of the guides was a determined attempt at the popularization of a new consensus on religious liberty in public education. The consensus was reached in the 1980s by diverse educational, religious and civil-liberty groups. The rationale behind the agreement was to put an end to almost two centuries of confusion and conflict over religious liberty issues in public schools. 
The objective of this article is to examine the role of the guides in the dissemination of religious freedom ideals as outlined by the new consensus proponents. More specifically, how is the new consensus civic framework of the religious-liberty clauses evidenced in the specific guidelines addressing typical school situations. First, the statements forming the consensus framework will be presented, with a special focus on the requirements of objectivity and neutrality in teaching about religion. In the subsequent part, the content of the selected guides will be examined for their correlation with the consensus framework. Finally, the author will attempt to assess the impact the guides have exerted on the American system of education.

For the sake of clarity, the examination of the guides will be limited to the ones addressed to school officials, teachers and parents in elementary and secondary schools, and their relation to internal school affairs. Most of the guides selected for consideration are a part of a collective First Amendment publication edited by Charles Haynes under the title Finding Common Ground: A Guide to Religious Liberty in Public Schools (2001). The selected pamphlets will include: A Teacher's Guide to Religion in the Public Schools, Religion in the Public Schools Curriculum: Questions and Answers, Religious Holidays in the Public Schools: Questions and Answers, The Equal Access Act: Questions and Answers and A Parent's Guide to Religion in the Public Schools. The discussion on the guidelines regulating the use of the Bible in public schools will be mainly based on another guide The Bible and Public Schools (Haynes, 1999). To emphasize the fact that the consensus was reached by a wide spectrum of groups, also included in the discussion are two other guides Protecting Religious Liberty in Public Schools. A School Official's Guide (McCoy, 2010) and Religion in the Public Schools: A Road map for Avoiding Lawsuits and Respecting Parents' Legal Rights (Lofaso, 2009) issued by American Civil Liberties Union (ACLU) and Americans United for Separation of Church and State respectively.

\section{THE HISTORICAL BACKGROUND TO THE NEW CONSENSUS GUIDELINES}

The significance of the guides cannot be fully assessed without prior examination of the origin and nature of the controversy and conflict the guides were meant to address. When the public school system was first established in the nineteenth century, American education was de facto Protestant. However, around the turn of the twentieth century, massive waves of immigrants representing other faiths or Christian denominations led to the gradual religious diversification of American schools. Over the course of years, the pressure of increasing religious diversity resulted in an informal "disestablishment" of the Protestant model.

Further complications emerged as religious pluralism became gradually acknowledged on the federal and legal level. In the 1940s the Supreme Court began to apply the Bill of Rights to the states, which initiated the process of restructuring of the relationship between religion and public education (Marty, \& Moore, 2000, p.40). Instrumental in this process was a series of the Supreme Court cases that gradually eliminated religious elements from public schools. The climax was reached with the Supreme Court ruling against state-sponsored school prayer 
(Dierenfield, 2007) and Bible readings. Many public schools misunderstood the ruling to mean that the First Amendment prohibits schools from making any mention of religion in any context (Murray, 2008, pp. 98-99). As a result, in an increasing number of public education institutions, the first school model, "the sacred public school," was replaced by a new one, "the secular public school" (Haynes, \& Thomas, 2001, pp. 5-6)

The tension between these two approaches to the place of religion in public education has been frequently referred to as "culture wars." Although the term is relatively recent, the phenomenon has a long-standing tradition in the American Public Square, its origins dating back to wars over civil rights and Vietnam (Fraser, 1999, p. 153). Over the twentieth century, however, the major battles of this war were fought in all areas of the school curriculum between secular and religious interpretations of the world. The controversies seem to have occurred with great frequency and embraced a wide range of topics. On one side of the battleground were "conservatives," who opted for reintroduction of religion into the school system. On the other were "liberals," who would advocate for keeping religion out (Nord, \& Haynes, 1998).

Since these controversies were heavily regulated by the law, public school teachers and principals, school board directors, and other school officials were left vulnerable to legal liability. As a result, many educators would often find themselves under pressure from parents whose requirements contradicted one another: some of them threatening to sue if the school acts in one way and others threatening to sue if the school acts in a contrary way. The situation was further complicated by the fact that religious issues in public schools were governed by multiple sources of law, ranging from federal and state constitutional law to school board policies. Even the pertinent constitutional clauses that govern the most common disputes involving religion in public schools: the Establishment, Free Exercise, and Free Speech Clauses of the United States Constitution's First Amendment, posed the difficulty for many schools of how to permit religious liberty without endorsing religion (Lofaso, 2009, p. 13).

The mid-1980s, however, witnessed a growing concern over the failure to address the issue of religion in the system of education. Ongoing bitter culture wars gave rise to an increasing awareness among both politicians and educators of the need to treat religion seriously and to fundamentally transform the public school status quo from a "battleground" to a "common ground" (Haynes, 2001). In the face of increasing religious diversification of students, the necessity to address the challenge became even more pressing.

With this end in mind, beginning in the late 1980s, coalitions of civil liberty, religious, and educational groups joined their efforts to develop a common educational framework on the constitutional role of religion in public school. The cooperation resulted in a series of agreements that formed the basis on what became to be referred to as a new consensus on teaching about religion and religious liberty. In 1988 an agreement was reached on Religion in the Public School Curriculum - the first common ground statement in American history on the importance of teaching about religion in public schools. The agreement was followed by other consensus statements in 
the coming years: Religious Holidays in Public Schools (1989), Equal Access Act (1991), Religious Liberty, Public Education, and the Future of American Democracy: A Statement of Principles (March, 1995) and Religion in the Public Schools: A Joint Statement of Current Law (April, 2005). The Joint Statement (American Jewish Congress, 1995) was a crucial agreement on what the then-current law said about religious expression in public schools on issues such as student prayers, distribution of religious literature, and student garb (Carper, \&Hunt, 2009, pp. 154-155).

That same year U.S. Secretary of Education Richard Riley issued: Religious Expression in Public Schools - the guidelines that in August 1995, at President Bill Clinton's directive, were sent to every superintendent in the nation, as mentioned in the introduction of this paper. Motivated by their success, the Secretary urged the First Amendment Center to create consensus guidelines addressed specifically to parents and teachers. The resultant guides, A Parent's Guide to Religion in the Public Schools and A Teacher's Guide to Religion in the Public Schools, were released in 1996 and 1998 respectively. Both of them were based on the consensus reached in earlier guidelines and were a part of the historic mailing campaign indicated in the first lines of this paper.

The list of the guides would not be complete without mentioning three other important pamphlets: Religion in the Public Schools Curriculum: Questions and Answers (1990), The Equal Access Act: Questions and Answers (1990) and The Bible and Public Schools: A First Amendment Guide (1999). All three were the result of reaching an agreement between numerous religious and educational bodies. The first guide specifies the place of religion in the curriculum and defines teaching about religion as opposed to religious indoctrination. The second guide outlines the provisions of The Equal Access Act that regulate the functioning of student clubs. Finally, The Bible and Public Schools: A First Amendment Guide addresses the issue of the place of the Bible in schools, one of the longest-running conflicts in the history of public schools (Carper, \& Hunt, 2009, p. 157).

\section{THE NEW CONSENSUS CIVIC FRAMEWORK OF THE RELIGIOUS-LIBERTY CLAUSES}

The examination of specific guidelines included in the guides is not possible without the consideration of the rationale that stands behind them. The rationale is outlined in several important new consensus pamphlets: Religion in the Public School Curriculum: Questions and Answers, Religious Holidays in the Public Schools, and Equal Access and the Public Schools: Questions and Answers (American Academy of Religion,1990, pp. 87-92; American Academy of Religion,2001, pp. 103-109; American Academy of Religion,1990, pp. 118-124). Since a detailed discussion of all the statements articulated in the pamphlets goes beyond the scope of this paper, the author will limit the examination to the core new consensus statements. The statements are articulated in Principle IV of Religious Liberty, Public Education, and the Future of American Democracy: A Statement of Principles (Freedom Forum First Amendment Center, 1995). They are considered to form a civic framework for the religious liberty clauses of the First Amendment, and consequently provide the following definition of religious liberty in public schools: 
Public schools may not inculcate nor inhibit religion. They must be places where religion and religious conviction are treated with fairness and respect.

Public schools uphold the First Amendment when they protect the religious liberty rights of students of all faiths or none. Schools demonstrate fairness when they ensure that the curriculum includes study about religion, where appropriate, as an important part of a complete education (p. 12).

As evident from the definition, the new consensus approach seeks to establish a balance between the two models of schools: "the sacred public school" and "the secular public school." Most importantly, it reaffirms the place of religion and religious conviction in public education as essential civic values that are to be treated with fairness and respect. It also upholds the religious liberty rights guaranteed in the Free Exercise Clause, with the reservation that it is the rights of students that are to be protected. The fairness in treatment of students regardless of their religious affiliation, or the lack of it, is also emphasized. The last part of the definition addresses the place of religion in the curriculum, here referred to as "study about religion," as the only constitutionally approved form of conducting religious education. Basing on the definition, Ch. Haynes (2001, p. 74) formulates the following principles that constitute the policy of new consensus on teaching about religion:

1. As the Supreme Court has made clear, the study of religion in public schools is constitutional.

2. Because the study of religion is vitally important if students are to be properly educated about our history and culture, it is essential to include religion in the curriculum.

3. Religion must be taught objectively or neutrally; it must be the purpose of public schools to educate students about a variety of religious traditions, not to indoctrinate them into any particular tradition

Apart from the claim on constitutionality of religious education, the policy justifies the presence of this type of education in the curriculum as a vital part of an all-round education. How the requirements of neutrality and objectivity are to be applied to the teaching of religion is articulated in one of the First Amendment agreement statements Religion in the Public School Curriculum: Questions and Answers (American Academy of Religion, 1990, pp. 87-92). Under the provision of the statement, to properly distinguish teaching about religion from religious indoctrination, the schools are required to apply the following criteria:

1. The school's approach to religion is academic, not devotional.

2. The school may strive for student awareness of religions, but should not press for student acceptance of any one religion.

3. The school may sponsor study about religion, but may not sponsor the practice of religion.

4. The school may expose students to a diversity of religious views, but may not impose any particular view.

5. The school may educate about all religions, but may not promote or denigrate any religion.

6. The school may inform the student about various beliefs, but should not seek to conform him or her to any particular belief (Haynes, 2001, pp. 89-92). 
As is evident from the criteria, having acknowledged the constitutionality of religious studies, the new consensus proponents also established strict boundaries to the teaching procedures pertaining to the subject.

In the subsequent part of the paper the above-mentioned elements of the consensus framework will be discussed in relation to the specific instructions included in the guides. The instructions address all areas of school life that are prone to the violation of religious freedom, such as religious expression of students, religious expression of teachers, and the place of religion in the curriculum. The format accepted in the paper loosely follows the order of the specific statements as they appear in the definition of religious liberty formulated by the consensus. Also discussed is the issue of student clubs and the principle of equal access outlined in Equal Access Act. Since no study of new consensus common ground can be complete without the consideration of common ground rules, a brief examination of the rules, as they are presented in the guides, is included in the final part of the discussion.

\section{"PUBLIC SCHOOLS MAY NOT...INHIBIT RELIGION" - STUDENTS' RELIGIOUS RIGHTS PROTECTED}

With regard to students' religious expression, the issues covered in the guides include all vital religious activities, such as a prayer, religious discussion, reading the Scriptures, dress and dress codes, student religious clubs and distribution of religious materials. All of these forms of expression are interpreted in the light of the Free Exercise Clause and its requirement of prohibiting the inhibition of religion.

The religious activity that is given coverage in most of the guides is student prayer (Haynes, 2001, pp. 83, 144-145; McCoy, 2010, pp. 4-5; Lofaso, 2009, pp. 29, 36, 41-44). Special emphasis is placed on the fact that it was exclusively institutionalized prayer i.e. state-sponsored or state-organized that was struck down by Supreme Court's decisions of the early 1960's (Haynes, 2001, p. 144). Thus, all forms of student-initiated prayer are permissible: students are free to pray alone or in groups, before or during athletic events, or when they gather around the flagpole for prayer before school begins. They are also permitted to pray silently during the school-organized "minute of silence," or other quiet periods. Students are allowed to pray during non- instructional time, e.g. say grace before meals, and pray before tests. They may also pray silently in the classroom, except when required to be actively engaged in school activities. If necessary, they may be excused from class to take part in prayers. Under this provision, e.g. Muslim students may be briefly excused from class to fulfill their religious obligations to pray during Ramadan.

Dress and dress codes are another vital part of students' religious expression that is extensively covered by the guides (Lofaso, 2009, pp. 86-90; Haynes, 2001, p. 147; McCoy, 2010, p. 10). The guides emphasize the fact that a great measure of freedom is guaranteed in the Constitution in this respect, e.g. students obliged to wear religious attire such as head scarves or yarmulkes can do so in school. Students may also display religious messages on jewelry or clothing to the same extent that other messages are permitted. Unless the message is considered vulgar, lewd, one enco- 
uraging violation of law or causing a substantial disruption or materially interfering with classroom activities, schools cannot prohibit students from wearing religious messages or symbols, even if the schools do not agree with the viewpoint expressed.

Besides dress and jewelry, another means that may be used by students to express their religious beliefs is students' assignments. Here, as is the case with already presented issues, students enjoy a great deal of freedom. As articulated in Religious Expression in Public Schools, the guidelines published by the U.S. Department of Education, "Students may express their beliefs about religion in the form of homework, artwork, and other written and oral assignments free of discrimination based on the religious content of their submissions. Such home and classroom work should be judged by ordinary academic standards" (United States Department of Education, 1995, p. 128). Students may exercise the same freedom to express religious views during a class discussion. However, if a student's insertion of his or her religious beliefs into class work is found irrelevant, teachers should address it as they would any other off-topic comments (American Civil Liberties Union of New Mexico [ACLU], 2010, p. 15).

As evidenced in the guides, constitutionally guaranteed measure of freedom, upheld in the new consensus civic framework, is implemented in specific instructions addressed to school officials, students and parents.

\section{"PUBLIC SCHOOLS UPHOLD THE FIRST AMENDMENT WHEN THEY PROTECT THE RELIGIOUS LIBERTY RIGHTS OF STUDENTS OF ALL FAITHS OR NONE" - WHEN INDIVIDUAL'S RIGHTS ARE INFRINGED}

Apart from instances when religious activity rests solely within the responsibility of an individual student, the guides discuss situations when an individual's freedom might be infringed by the freedom of fellow students. Thus, it is emphasized that any religious activity that students have a right to exercise must be truly voluntary and non-disruptive, free from any forms of religious discrimination and coercion.

For this reason, in any situation involving religious activities, students do not have a right to force a captive audience to participate in religious exercises. For example, according to general provisions, students are allowed to read their Bibles or other scriptures, and discuss religion with other willing student listeners. However, the engagement in religious discussion must be free from discrimination and must not include the right to have a captive audience listen, or to compel other students to participate. Teachers and school administrators should ensure that no student is in any way coerced to participate in religious activity (Haynes, 2001, p. 127).

Possibly, the same idea of non-infringement undergirds the constitutionality of the recitation of the Pledge of Allegiance. Under the provision of the Free Speech Clause which not only guarantees freedom of expression, but also protection against coerced speech - students have the right to opt out of the Pledge (Haynes, 2001, p. 46).

Offering prayers by students at graduation is reported as an issue lower courts are divided about, and parents are suggested to seek legal advice about what rules apply in their state. (Lofaso, 2009, p. 39-41). However, to satisfy the requirement of protecting the religious liberty rights of students of all faiths or none, an "invoca- 
tion" or "benediction" may not be part of the graduation official program, even if conducted by a student; nor may the school allow the student to lead the audience in prayer (McCoy, 2010, p. 5).

Some of the guides mention organizing religious Baccalaureate ceremonies. The general approach accepted in the documents is that these services may be held on campus, provided that the school allows community groups to rent or otherwise use its facilities after hours. The ceremonies are required to be held separately from the school's graduation program, and be entirely voluntary, meaning that they are not sponsored, advertised, nor supervised by school officials. The terms offered to these services cannot be any different than those offered to any private group, e.g. the school may announce the baccalaureate in the same way it announces other community events (McCoy, 2010, p. 5; Haynes, 2001, p. 145).

\section{"PUBLIC SCHOOLS MAY NOT INCULCATE...RELIGION" - THE REQUIREMENT OF OBJECTIVITY AND NEUTRALITY IN MATTERS OF RELIGION}

The requirement of the government's non-entanglement with religion expressed in the Establishment Clause is evidenced in the prohibition of the inculcation of religion by public schools. This means that school administration and educators are to remain "neutral" in matters of religion when acting in their official capacity. In other words, they may not "endorse" religion by any form of religious activity while carrying out their school duties. For this reason they are forbidden to "endorse" prayer, i.e. to lead or encourage prayer in any form at school or at school-sponsored events. They may not, for example, require or encourage students to recite prayers, pray with or in the presence of students, or organize a "student initiated" prayer (Haynes, 2001, p. 81-83). Similarly, schools may not "endorse" the reading of the Scripture by, for instance, starting each day with a Bible reading (Lofaso, 2009, p. 28).

However, there is some measure of freedom that is granted to teachers, under specified conditions. For example, if a group of teachers wishes to meet for prayer or scriptural study outside the presence of students, and in a way that is non-disruptive for other teachers or interferes with their duties, they are free to do so. Teachers are also allowed to wear non-obtrusive jewelry, such as a cross or a Star of David, but - unlike students - they cannot wear clothes with proselytizing messages (Haynes, 2001, pp. 81-82).

\section{"SCHOOLS DEMONSTRATE FAIRNESS WHEN THEY ENSURE THAT THE CURRICULUM INCLUDES STUDY ABOUT RELIGION, WHERE APPROPRIATE, AS AN IMPORTANT PART OF A COMPLETE EDUCATION" - THE PLACE OF RELIGION IN THE SCHOOL CURRICULUM}

Besides specifying the civic framework for student's religious expression, the guides address another core concept of the new consensus ideology, i.e. the place of religion in the school curriculum. Undergirding all topic-related guidelines pro- 
vided in the guides are the already-mentioned three major principles forming the consensus on the study about religion: the constitutionality of the study; its significance in terms of the provision of proper education about history and culture; and, lastly, objectivity and neutrality in the approach towards religion in the teaching process.

The teaching about religion is repeatedly referred to as distinguished from religious indoctrination. To be able to distinguish between the two, teachers and school officials are reminded of the guidelines included in Religion in the Public School Curriculum: Questions and Answers, which stress the requirement of an academic rather than devotional approach towards religion (American Academy of Religion, 1990, p. 90). Also echoed in the guides are the principles articulated in another crucial statement, Religious Liberty, Public Education, and the Future of American Democracy: A Statement of Principles (Vanderbilt University, 1995) namely the requirement of neither inculcating nor inhibiting religion, but treating it with fairness and respect.

Study about religion is suggested to be included within curriculum subjects, "wherever it naturally arises" (Haynes, 2001, p. 91), or in special courses, i.e. electives offered by some secondary schools. On the secondary level, the social studies, literature, and the arts are recommended as offering numerous opportunities for the inclusion of information about religions, their ideas and practices. On the elementary level, such natural opportunities are said to be created in discussions of the family and community life, and instruction about festivals and different cultures (Haynes, 2001, p. 76).

Extensive instructions on how to determine which religions should be taught as well as how much should be said both in the elementary grades and on the secondary level are provided by A Teacher's Guide to Religion in the Public Schools (Haynes, 1998). Teaching about religion, devoid of religious instruction, may embrace the history of religion, comparative religion, the Bible (or other scripture)-as-literature, and the role of religion in the history of the United States and other countries. Religious influences on art, music, literature, and social studies are also considered to be permissible public school subjects.

More specific guidelines on the teaching about the Bible in the light of the consensus directives can be found in The Bible and Public Schools: A First Amendment Guide (Haynes, 1999, p. 5-13). The guide addresses issues such as selecting a Bible and the way of its interpretation for use in literature, history or elective Bible courses. Also discussed is the study of the Bible in elementary education as well as in history, literature or in elective courses that deal with the Bible on the secondary level.

\section{RELIGIOUS HOLIDAYS AND SYMBOLS}

Teaching about religion would not be complete without the consideration of religious holidays and symbols. Thus, most guides offer more or less specific instruction on how to treat religious holidays in the classroom. The most specific guidelines are provided in Religious Holidays in the Public Schools: Questions and Answers (American Academy of Religion, 2001). The guides are very clear on the Supreme Court requirements for the recognition of the constitutionality of religious holidays in the school 
settings: "The recognition of holidays may be declared constitutional if the purpose is to promote secular instruction rather than promotion the particular religion involved" (Haynes, 2001, p. 106). Thus, what is stressed is the idea that teaching about religious holidays must serve objective, academic goals of educating students about history and cultures, and may not involve the observance of holidays as religious events or promotion of such observance by students.

Similarly, religious symbols may be used only as examples of cultural or religious heritage and can be only temporarily displayed as part of an academic lesson or during holiday time, as long as these symbols are displayed with other holiday decorations reflecting different beliefs or customs. Assigning or suggesting the creation of artwork with religious symbols is not regarded permissible nor is organizing religious music-dominated programs, especially when it coincides with a particular holiday.

\section{TEACHING EVOLUTION}

A number of guides address the issue of teaching evolution when discussing the public school curriculum in the context of religion. The issue is covered more or less exhaustively depending on who the guide is addressed to. The most in-depth coverage can be found in Religion in the Public School: A Road Map for Avoiding Lawsuits and Respecting Parents' Legal Rights (Lofaso, 2009, p.65-68). However, the following guidelines included in Protecting Religious Liberty in Public Schools: A School Official Guide seem to best summarize the new consensus approach propagated by the guides:

1. Schools cannot ban the teaching of evolution (Epperson v. Arkansas, 1968).

2. Creationism, Intelligent Design and other "creation science" theories cannot be taught alongside evolution (Edwards v. Aguillard, 1987; Kitzmiller v. Dover Area Sch. Dist, 2005).

3. Teachers do not have "academic freedom" to teach creationism of their own accord (Peloza v. Capistrano Unified School District, 1994).

4. Teachers cannot refuse to teach evolution because of their personal religious beliefs (LeVake v. Independent Sch. Dist., 2001) (pp.8-9).

The position expressed in the guides is that teaching creationism should be limited to discussion in religious studies class or in any course that considers religious explanations for the origin of life (Haynes, 2001, p. 92).

\section{CHARACTER EDUCATION}

With regard to the relationship between religion and character education in public schools, the guides underline the role of parents as the first and most important moral educators of their children. Thus, it is recommended that it should only be in cooperation with parents and the community that character education programs can be developed.

The guides stress that the public schools are obliged to neither promote nor denigrate religion when teaching the core moral and civic values agreed to in the community. Consequently, they must perform the task keeping the right balance: 
free from religious indoctrination, and at the same time not suggestive that religious authority is unnecessary or unimportant or that morality is simply a matter of individual choice without reference to absolute truth (Haynes, 2001, pp. 80, 148).

\section{EXCUSAL REQUEST}

Of equal importance in exercising religious freedom, and the freedom of conscience in particular, is the possibility of excusing students from classroom discussions, assignments, or activities for religious reasons. Addressing the issue, the guides express an opinion that, whenever possible, school officials should try to accommodate such parental requests in order to strike a balance between the student's religious freedom and the school's interest in providing a well-rounded education.

As stated in Parent's Guide to Religion in the Public School, "If it is proved that particular lessons substantially burden a student's free exercise of religion and if the school cannot prove a compelling interest in requiring attendance, some courts may require schools to excuse the student" (National PTA and the First Amendment Center, 2001, p. 146). Religious Expression in Public Schools, however, makes it also clear that "students generally do not have a federal right to be excused from lessons that may be inconsistent with their religious beliefs or practices. School officials may neither encourage nor discourage students from availing themselves of an excusal option" (United States Department of Education, 1995, p.129, see also Lofaso, 2009, pp. 61-63).

\section{RELEASED TIME}

Another popular form of accommodating student's religious needs is the so called "released time," when students, with the consent of their parents, are excused from public school in order to participate in religious instruction. The guides agree on the fact that schools have the discretion to dismiss students to off-premises religious instruction (Haynes, 2001, p. 148). The released time, however, is also subjected to some restrictions, e.g. "the student may not be excused for more than one hour each school day at a time period not in conflict with the academic program of the public school. All excuses are subject to the approval of the local school board. Religious instruction cannot be conducted on school property, nor can school representatives assume responsibility for the instruction" (McCoy, 2010, p.18). As is the case with other religious freedom issues, the schools must remain objective and neutral: they may not encourage or discourage participation or penalize those who do not attend; nor may they allow religious instruction by outsiders on school premises during the school day.

\section{THE APPLICATION OF THE RULE OF EQUALITY: STUDENTS' RELIGIOUS CLUBS}

Another vital element of student religious expression is the issue of students' religious clubs, discussed in most examined guides, particularly in The Equal Access Act: Questions and Answers (American Academy of Religion, 1990). The issue 
is presented in the light of the already- mentioned Equal Access Act. The emphasis is placed on non-discriminatory and non-preferential treatment of the religious clubs. The equal treatment must embrace the content or viewpoint of the group's message as well as the regulations concerning the use of school facilities, i.e. access to meeting spaces, public address system, bulletin boards, yearbook pages, etc. The guides also underline the requirements of non-disruptive manner of the club operation as well as the school's neutrality in terms of the sponsorship or initiation of and participation in the club's activities.

The same "equal access" principle is strongly articulated in relation with the distribution of religious materials (McCoy, 2010, p. 14), including the Bibles (Haynes, 1999, p. 5). Namely, if a school has created an open public forum in which any and all community groups can distribute materials, some courts have held that religious groups may distribute materials to students under the same terms as any other group. The distribution, however, must proceed in compliance with any reasonable restrictions on the time, place and manner of distribution.

\section{COMMON GROUND RULES}

As stressed in the guides, though much has been settled by federal or lower-level courts, there is still a great deal of work to be done on the ground to reach real consensus in the field of religious liberty. Whatever the issue that remains to be worked out in the communal debate, the guides promote the idea first articulated in the Williamsburg Charter, "The issue is not only what we debate, but how" (Haynes, 2001, Appendix B, p. 238).

Indispensable in this context are the common ground civic rules that have been established by the new consensus proponents (Haynes, 2001, p. 61-62). Though none of the examined guides discusses the rules in their entirety, one of the guides, A Parent's Guide to Religion in the Public Schools (National PTA and the First Amendment Center, 2001), not only covers most of the rules, but also gives them a prominent place in its layout.

The five common ground civic rules included in the document are: include all of the stakeholders; listen to all sides; work for comprehensive policies; be pro-active, and commit to civil debate. Addressing the rules, the guide emphasizes the necessity of ensuring appropriate involvement of parents - especially those holding dissenting views - in the decision making process. It encourages both sides to truly listen to each other: school officials to be attentive to criticism of school policies and practices concerning the treatment of religion and religious perspectives, and parents with deep religious convictions to acknowledge the non-hostile and fair attitude of public school administrators and teachers. The guide prompts the schools to take a pro-active approach to conflict and controversy by working with parents to develop comprehensive policies concerning religious liberty issues. And, finally, it promotes a civil model of debate based on the principles of civility and respect, accuracy and fairness as well as learning through constructive dialogue (Haynes, 2001, p. 143). 


\section{THE IMPACT THE GUIDES HAVE EXERTED ON THE AMERICAN SYSTEM OF EDUCATION}

The mailing of the guides in January 2000 marked the first time that every public school was provided with the guidelines that can be used to develop polices on religion and religious expression in their schools. As James Carper and Thomas Hunt argue, due to the fact that the various guides were endorsed by broad coalitions, they provided "a legal safe harbor (or at least the closest thing to it) for school boards, administrators and teachers" (2009, p. 157).

Measuring the impact of the New Consensus on policies and practices in public schools is not easy, however, since no research has been done into the field as to date. Some definite signs of change are evident in school districts that utilized the new consensus guidelines to form their own religious freedom practices and policies. As stated by J. Carper and T. Hunt (2009, p.158), “The common ground documents on religion in schools have played a critical role in helping many school districts translate these developments into new policies and practices consistent with the First Amendment and widely accepted by the community". Some of these programs have been launched and supported by nationwide initiatives such as First Amendment Schools or 3Rs projects.

First Amendment Schools: Educating for Freedom and Responsibility is a project co-sponsored by the Association for Supervision and Curriculum Development (ASCD) and the First Amendment Center. The objective of the project is to create laboratories of democratic freedom by providing students and all members of the school community with substantial opportunities to practice democracy. One way in which the principles of freedom and democracy can be upheld is when religious liberty rights are protected. Working to this end, the First Amendment Schools provide all members of the school community with daily opportunities to translate civic education on religious liberty rights into community engagement by addressing problems and issues in their communities (Haynes, 2001, p.170-173).

The project was first launched in May 2002 with the inaugural class of First Amendment Project Schools (FAS) - a diverse group of elementary, middle, and high schools serving urban, suburban, and rural communities - chosen by a blue-ribbon selection committee. At present, the FAS Network consists of nearly 100 schools - K-12 - and includes over 70,000 students: 17 project schools as well as 81 affiliated schools. This Network includes public, private, and charter schools that serve urban, suburban, and rural communities, reflecting the demographic, cultural, and economic diversity of the American nation (First Amendment Schools, n.d.).

Apart from the schools participating in First Amendment School initiative, there have been some other schools that utilized the new consensus guidelines to develop their own policies concerning religious liberty. Warren Nord and Charles Haynes give an example of schools in Wicomico County, Maryland, as models of successful implementation of the new consensus vision (Nord, \&Haynes, 1998, p.30-32). Developing their policy on religious freedom, the schools made sure to "include all of the stakeholders." Through town meetings and media, they kept the community fully informed and involved in reaching an agreement, which 
then was adapted by the school board and disseminated to school personnel and parents. All administrators were then required to take part in an intensive seminar that prepared them to apply the policy's religious liberty principles in their decision making. A number of teachers were sent to a national institute for special training and workshops were provided for many others on how to handle religion in the curriculum. New curricular resources were developed and others purchased to help teachers teach about religions more accurately and fully.

In consequence, the teachers in these schools are unafraid to take religion seriously in their classroom. Having learned how to implement the rules of rights, responsibility and respect, they engage their religiously diversified students in discussing religious issues on a regular basis. Students learn that their commitment to religious liberty must be tied to a civic responsibility to guard that right for every citizen, including those they strongly disagree with. They learn how to discuss religious issues in their classrooms without angry arguments about religion including name-calling and personal attacks, but with civility and respect (Nord, \& Haynes, 1998, p. 29-30).

3 Rs (Rights, Responsibilities, and Respect) Projects are developed by the First Amendment Center's Religious Freedom Programs in partnership with state educational organizations and departments. Like First Amendment Schools, it is a national initiative to teach civic virtue and mutual understanding in the public schools, using, among other sources, First Amendment pamphlets. The project has been run in a number of states, e.g. in Utah (Utah Civic Coalition, n.d.), yet the California project is said to be the thus far most fully developed one.

As claimed by John Brophy (2011, p. 21), who was the Steering Committee Chair of the California 3Rs Project for eight years, the common ground principles have had a tremendous impact on his school community. Firstly, they helped to devise the curriculum that incorporates the basic tenets of the world's major religions and the role of religious beliefs in shaping American history, world history, art, music. Secondly, they facilitated the implementation of a philosophy of dealing with differences with respect to other persons' opinions. Thirdly, they have prepared teachers, administrators, and local school boards to address the concerns of those with deeply held feelings about the role of religion in schools and to develop community based policies and procedures before conflicts arise. Fourthly, the California 3Rs Project has become the launch pad for other complimentary programs, like Conflict Resolution programs that educate in a practical application of the 3Rs virtues, and allow students to practice what they are learning in the classroom. Finally, practicing civil debate, seeking common ground, and developing policies with the community have become a framework for dealing with other potentially divisive issues

Despite some success, the new consensus ideals have not yet been widely implemented in American schools. A poll taken a year after the distribution of the guides showed that only $8 \%$ of administrators and $2 \%$ of teachers were very familiar with the guidelines. And a stunning 39\% of administrators and $69 \%$ of teachers were not at all familiar (Freedom Forum, n.d.). As Marcia Beauchamp observes, many school districts are still afraid to address the issues, and most have not taken a pro-active stance; many are still without effective policies, and in almost every case the curricu- 
lum still largely ignores religion (2002). The same view is expressed by Ch. Haynes (Freedom Forum, n.d): “....many, if not most, school leaders are still afraid to touch religion. Following the let sleeping dogs lie approach to school administration, they only begin to think about the First Amendment when a fight erupts - and by then it's often too late to avoid a lawsuit. That's why we continue to have so many schools that violate the law either by unconstitutionally promoting religion or by unconstitutionally denying the religious-liberty rights of students."

In the face of overt failure of the previous mailing, the U.S. government resolved to take slightly more drastic steps. In 2003, another set of guidelines was sent to public schools. They largely reiterated those of the Clinton Administration, restating the current status of the law. What was new, however, was the threat to withdraw federal funding from schools which violate the guidelines: powerful means to insure that schools fully respect the religious freedom of students and teachers (The Rutherford Institute, n.d.).

\section{CONCLUSION}

Having been distributed to every school principal throughout the country, the guides have undoubtedly become one of the main instruments used in the dissemination of the new consensus religious liberty framework. They define, clarify and propagate these ideals among all the agents of the educational stage: school administrators and teachers as well as parents and students. They address all areas of school life that are prone to the violation of religious freedom principles: students' religious expression, school curriculum, and the principles that govern the involvement of teachers and other school officials as well as parents in the religious activities on the school grounds.

Although the distribution of the guides did not result in a nationwide turnabout in the approach to religion in schools, it marked a significant turning point in the national policies about the place of religion in public education. Controversy and conflict still abound. However, there has been a growing number of schools where the adoption of the new consensus policies and practices has resulted in significant transformations. The controversies have been addressed and conflicts handled in a more civic and respectful manner than in the past, without bitter fights and lawsuits, thus bringing hope for similar transformations to take place on a wider scale in the future.

\section{REFERENCES}

American Academy of Religion. (1990). Equal Access Act: questions and answers. In: Ch. C. Haynes, \& O. Thomas (Eds.), Finding common ground: a guide to religious liberty in public schools. (pp. 118-124). Nashville, TN: First Amendment Center.

American Academy of Religion. (1990). Religion in the public schools curriculum: questions and answers. In: Ch. C. Haynes \& O. Thomas (Eds.). Finding common ground: a guide to religious liberty in public schools (pp. 139-148). Nashville, TN: First Amendment Center.

American Academy of Religion. (2001). Religious holidays in the public schools: questions and answers. In: Ch. C. Haynes, \& O. Thomas (Eds.), Finding common ground: a guide to religious liberty in public schools (pp. 103-109). Nashville, TN: First Amendment Center. 
American Jewish Congress, New York. (1995). Religion in the public schools: a joint statement of current law, April 1995. New York. Retrieved from http://eric.ed.gov/?id=ED387390.

Beauchamp, M. (2002). Guidelines on religion in public schools: a historic moment. Religious Studies News. American Academy of Religion. Retrieved from http://www.rsnonline.org/index. php?option $=$ com_content\&id $=688 \&$ Itemid $=785$

Brophy, J. (2011). Finding common ground in the most diverse society in the world: California. Religion and the Public Schools. Retrieved from http:/ / www.firstamendmentcenter.org/madison/wpcontent/uploads/2011/03/california3rs.pdf

Carper, J., \& Hunt, C. (Eds.). (2009). The Praeger handbook of religion and education in the United States. Westport, CT: Praeger Publishers.

DelFattore, J. (2004). The fourth R: conflicts over religion in America's public schools. New Haven, CT: Yale Univ. Press.

Dierenfield, B. J. (2007). The battle over school prayer: how Engel v. Vitale changed America. Lawrence, KS: University Press of Kansas.

Edwards v. Aguillard, 482 U.S. 578 (1987).

Epperson v. Arkansas, 393 U.S. 97 (1968).

Fraser, J. W. (1999). Between church and state: religion and public education in a multicultural America. New York: St. Martin's Press.

Freedom Forum First Amendment Center. (1995). Religious liberty, public education, and the future of American democracy. A statement of principles. Nashville, TN: The Freedom Forum First Amendment Center at Vanderbilt University.

Freedom Forum, (n.d.) Retrieved February 8, 2014, from http://www.freedomforum.org/templates/ document.asp?documentID $=17561$

Haynes, Ch. C. (1998). A teacher's guide to religion in the public schools. In: Ch. C. Haynes \& O. Thomas (Eds.), Finding common ground: a guide to religious liberty in public schools (pp. 69-86). Nashville, TN: First Amendment Center.

Haynes, Ch. C. (project coordinator). (1999). The Bible and public schools. A First Amendment guide. The Bible Literacy Project, Inc., First Amendment Center. Retrieved from www.freedomforum.org; www.biblecurriculum.org.

Haynes, Ch. C., \& Thomas, O. (Eds.).(2001). Finding common ground: a guide to religious liberty in public schools. Nashville, TN: First Amendment Center.

Kitzmiller v. Dover Area Sch. Dist., 400 F. Supp. 2d 707 (M.D. Pa. 2005).

LeVake v. Independent Sch. Dist. No. 656, 625 N.W.2d 502 (Minn. App. 2001), cert. denied, 122 S. Ct. 814 (2002).

Lofaso, A. M. (2009). Religion in the public schools: a road map for avoiding lawsuits and respecting parents' legal rights. Washington, D.C.: Americans United for Separation of Church and State.

Marty, M. E., \& Moore, J. (2000). Education, religion, and the common good: advancing a distinctly American conversation about religion's role in our shared life. San Francisco: Jossey-Bass.

McCoy, M. (Ed.). (2010). Protecting religious liberty in public schools. A school official's guide. American Civil Liberties Union of New Mexico. Retrieved from http://aclu-nm.org/wp-content/ uploads/2010/04/Religious-Liberty-in-Public-Schools-web.pdf.

National PTA and the First Amendment Center (2001). Parent's guide to religion in the public schools. In Ch. C. Haynes \& O. Thomas (Eds.), Finding common ground: a guide to religious liberty in public schools (pp. 139-148). Nashville, TN: First Amendment Center.

Nord, W. A., \& Haynes, Ch. C. (1998). Taking religion seriously across the curriculum. Alexandria, VA: Association for Supervision and Curriculum Development.

Peloza v. Capistrano Unified School District, 37 F. 3d 517, (9th Cir. 1994).

Rutherford Institute, (n.d.) Retrieved February 8, 2014, from https://www.rutherford.org/publications_resources/legal_features/New_Education_Department_Religion_Guidelines_May_Help_ Secure_Religious_Free

Utah Civic Coalition (n.d.). Retrieved February 8, 2014, from http://www.utahciviccoalition.org/profiles.html

United States Department of Education. (1995). Religious Expression in Public Schools. In: Ch. C. Haynes Ch., \& O. Thomas (Eds.), Finding common ground: a guide to religious liberty in public schools (pp. 127-129). Nashville, TN: First Amendment Center. 